\title{
SCIENTIFIC AND PRACTICAL ACTIVITIES OF ODESSA SCHOOL OF EARTHQUAKE ENGINEERING IN IMPROVING THE ASSESSMENT OF SEISMIC RISK
}

\author{
Iegupov K. V., Iegupov V. K., Murashko O. V.
}

\section{INTRODUCTION}

Odessa school of earthquake-resistant construction was created by professor V. K. Iegupov over the years of his work at Odessa Civil Engineering Institute (OCEI) from 1958 to 1968. After his departure from OIBI, the work was transferred by him to the Research Institute of Building Constructions (Kiev), and then to the Odessa Institute of Marine Engineers (OIME), where over the next 30 years, his team of employees actively continued this work. After his death, the team was headed by Professor K. V. Iegupov. In 2005, he was invited to Odessa State Academy of Civil Engineering and Architecture as the head of the department, where work on earthquake-resistant construction was continued.

In 2015, he was invited to take the position of Director of Science and Technology Institute of Fundamental and Applied Services of Odessa National Maritime University in Odessa.

Over the years, new directions in the field of earthquake-resistant construction have been created and developed. Studies of the earthquake resistance of buildings have been carried out in view of spatial work and wave processes. The basic laws of spatial deformation have been formulated, the scientific foundations of building modeling have been developed, and models for the interaction of structures with a traveling seismic wave have been created.

Fundamental research in the field of decomposition of extensive sets of equations made it possible to create a theory of building simulation. Based on this theory, the scientific team under his leadership carried out the following important for Ukraine and Odessa works: calculation of the earthquake resistance of the control unit of the Chernobyl nuclear power plant; calculation of seismic resistance of the bell tower of the Transfiguration Cathedral, scientific and technical support for the design of critical structures and highrise buildings.

The results of studies over the years are reflected in monographs ${ }^{1,2,3,4}$. Currently, a creative team is working on this issue: K.V. Iegupov,

${ }^{1}$ Yehupov V. K., Komandrina T. A. (1969) [Calculation of buildings for seismic impacts] "Budivelnik", Kyiv (in Russian). 
V.S. Dorofeev, S. I. Rogachko - Doctors of Technical Sciences, N. N. Soroka, A.V. Murashko, D. I. Bezushko, A. A. Baranova - Candidates of Technical Sciences.

An important contribution to the science of earthquake engineering is the work of Kostiantyn Viacheslavovych Iegupov on the spatial interaction of structures with the base, taking into account the uneven field of ground vibrations. In 2012, he defended his doctoral thesis "Earthquake Resistance of Reinforced Concrete Frame Buildings and Structure". The results of these studies are brought to major use and are included in the regulatory documents of Ukraine.

\section{PRACTICAL ACTIVITIES}

Based on the research, the creative team of Odessa school of earthquakeresistant construction took an active part in the development of the National Codes of Ukraines: DBN (Ukrainian national codes) V.1.1-12:2006 Construction in seismic regions of Ukraine, 2006; DBN (Ukrainian national codes) V.1.1-12:2014 Construction in seismic regions of Ukraine, 2014; DBN (Ukrainian national codes) V.3.2-2-2009 Residential buildings. Reconstruction and overhaul, 2009; DBN (Ukrainian national codes) V.2.4-3:2010 Hydraulic structures. Key Points, 2010; DBN (Ukrainian national codes) V.1.1-24:2009 Protection from hazardous geological processes. The main provisions of the design, 2010; DSTU (National Standards of Ukraine)-B-V.1.1-28:2010 Protection from dangerous geological processes, harmful operational influences, fires. Seismic Intensity Scale, 2010.; EUROCODE 8 DESIGN OF STRUCTURES FOR EARTHQUAKE RESISTANCE - Part 1: General rules, seismic actions and rules for buildings (EN 1998-1:2004, IDT), 2011.

In October 2006, in order to expand its influence on the construction industry in the Odessa region, a joint integrated laboratory for earthquake resistance and reliability of buildings and structures was created (Odessa State Academy of Civil Engineering and Architecture, Odessa and the State Enterprise Research Institute of Building Structures, Kyiv).

${ }^{2}$ Yehupov V. K., Komandrina T.A., Goloborodko V. N. (1976) Prostranstvennye raschety zdaniy (posobie po proektirovaniyu) [Spatial calculations of buildings (design manual)], "Budivelnik", Kyiv (in Russian).

${ }^{3}$ Yehupov V. K., Yehupov K.V., Lukash E.P. (1982) Prakticheskie metody rascheta zdaniy na seysmostoykost' [Practical methods of calculating buildings for earthquake resistance]. "Budivelnik", Kyiv (in Russian).

4 DBN 1.1-12: 2014.(2014) Stroitel'stvo v seysmicheskikh rayonakh Ukrainy [Ukrainian national construction regulation. Construction in seismic areas of Ukraine]. Kyiv : Ministry of Regional Development of Ukraine, Ukrarkhbudinform (in Ukrainian)

${ }^{5}$ Nemchinov Yu. I. (2008) Seysmostoykost' zdaniy i sooruzheniy [Seismic resistance of buildings and structures]. In 2 parts (in Russian). 
K. V. Iegupov became a direct participant in the creation and supervisor of this laboratory. The tasks of the laboratory include a wide range of issues related to ensuring earthquake resistance and reliability of buildings and structures in difficult engineering and geological conditions for the construction in the Odessa region. Currently, cooperation is being conducted with large construction organizations in Odessa and the region.

To study the level of seismic hazard in the Odessa region and to clarify the influence of local ground conditions on the magnitude of seismic impacts by Academy of Civil Engineering and Architecture and Subotin Institute of Geophysics of NASU, with the active participation of K.V. Iegupov, the first seismic station in Odessa was created in 2008 and work on seismic microzoning began. These works made it possible to clarify the seismic hazard of the Odessa region and to develop updated models of seismic impacts for designing critical structures.

\section{DETERMINATION OF LOADS AND IMPACTS ON HIGH CRITICAL BUILDING OBJECTS}

Safety requirements and desire to reduce the cost of buildings and structures create a problem, which is highlighted in connection with the high growth rate of construction. In modern cities, where the technogenic load on construction sites is sharply increasing, reliable information on the magnitude of the vulnerability of structures and the level of seismic hazard is a necessary condition for sustainable development.

Ensuring the safety of construction projects is currently one of the most relevant and important tasks of state policy in the field of national security. The modern methodology and methods for assessing seismic hazard make it possible to correctly evaluate the predicted seismic impacts for different periods of event recurrence with a given degree of relative seismic risk (Fig. 1). The results of studies by Ukrainian seismologists convincingly indicate that the seismic hazard in the Odessa region until 2007 was significantly underestimated on maps of the general seismic zoning of the SR-78. The probability of earthquakes with an intensity of 7 points in this area is quite high (Table 1).

Table 2 shows a list of destructive earthquakes that occurred in the seismically active Vrancea zone, and the intensity of their manifestations in large cities of Moldova, Ukraine and Russia ${ }^{6}$.

${ }^{6}$ DBN V.1.1-12: 2006. (2006) Stroitel'stvo v seysmicheskikh rayonakh Ukrainy [Ukrainian national construction regulation. Construction in seismic areas of Ukraine]. Kyiv : Ministry of Construction, Architecture and Housing and Communal Services of Ukraine, Ukrarchbudinform. (in Ukrainian). 


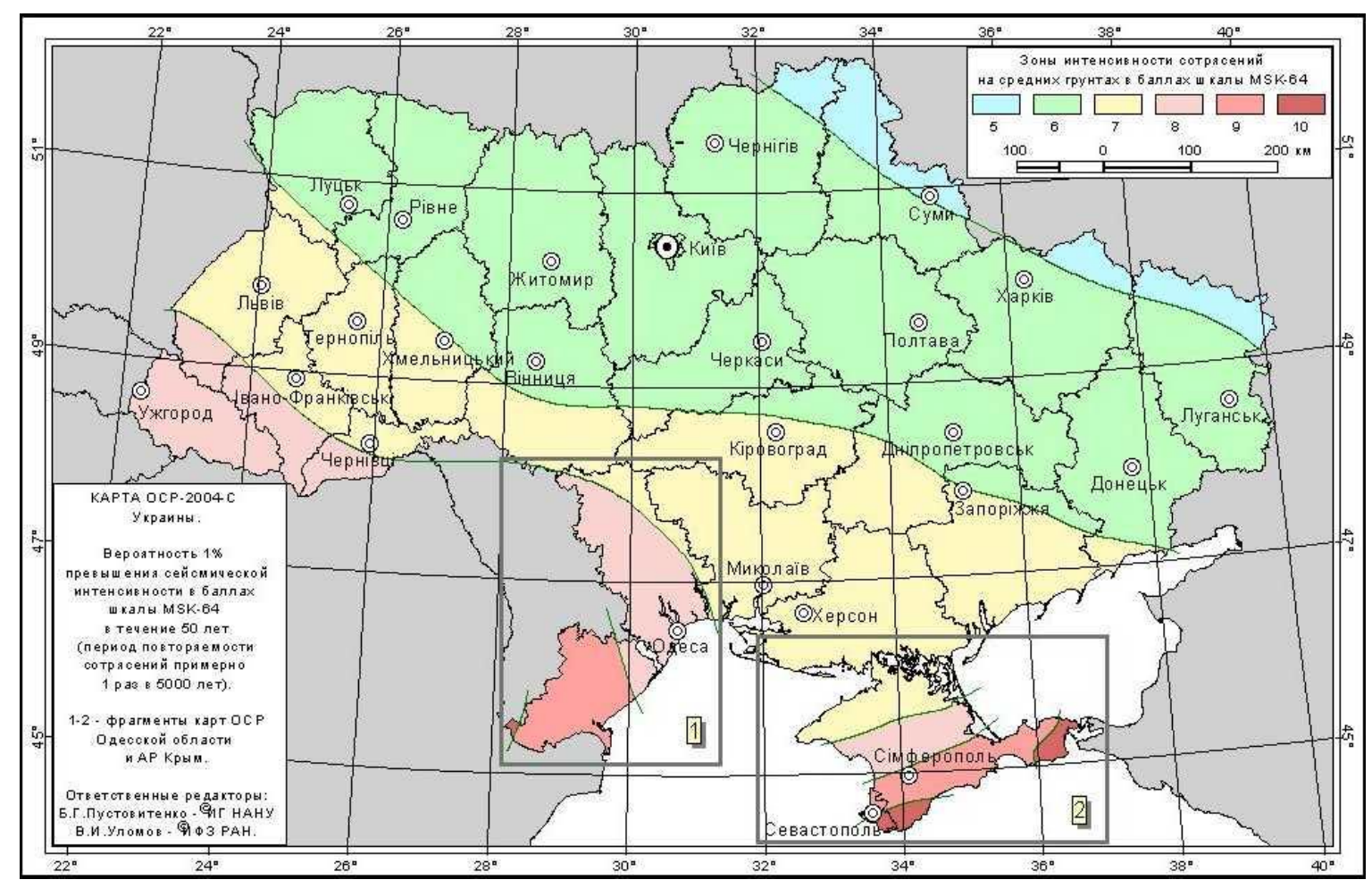

Fig. 1. Map of the general seismic zoning of Ukraine for a probability of $1 \%$ excess of seismic intensity in scale points for Ukraine over 50 years

Table 1

Seismic events with magnitude $>4$ in 2008-2017

\begin{tabular}{|c|c|c|c|c|c|c|c|c|c|c|}
\hline Year & 2008 & 2009 & 2010 & 2011 & 2012 & 2013 & 2014 & 2015 & 2016 & 2017 \\
\hline Magnitude & $\begin{array}{l}0 \\
\dot{p} \\
0 \\
\dot{+}\end{array}$ & $\begin{array}{l}m \\
\stackrel{n}{p} \\
0 \\
\dot{\sigma}\end{array}$ & $\stackrel{n}{\forall}$ & $\begin{array}{l}\infty \\
\dot{+} \\
0 \\
\dot{+}\end{array}$ & $\begin{array}{l}0 \\
\dot{I} \\
0 \\
\dot{\forall}\end{array}$ & $\begin{array}{l}m \\
\stackrel{n}{b} \\
0 \\
\dot{\gamma}\end{array}$ & $\begin{array}{l}\text { † } \\
\dot{\forall} \\
\dot{\gamma}\end{array}$ & $\stackrel{n}{+}$ & $\stackrel{\infty}{\dot{p}}$ & $\stackrel{\infty}{+}$ \\
\hline Quantity & 8 & 8 & 2 & 8 & 14 & 15 & 18 & 19 & 6 & 9 \\
\hline
\end{tabular}

Table 2

\section{Destructive earthquakes of the Romanian Carpathians (Vrancea zone)}

\begin{tabular}{|c|c|c|c|c|c|c|c|}
\hline \multirow{2}{*}{$\begin{array}{c}\text { Earthquake } \\
\text { date }\end{array}$} & \multirow{2}{*}{ Magnitude } & \multirow{2}{*}{$\begin{array}{c}\text { The intensity at } \\
\text { the epicenter, } \\
\end{array}$} & & \multicolumn{5}{|c|}{\begin{tabular}{c} 
Earthquake intensity in cities, points \\
\cline { 4 - 8 }
\end{tabular}} & & points & Chișinău & Lviv & Chernivtsi & Odessa & Kyiv \\
\hline 26.10 .1802 & 7,5 & $9-10$ & 7 & 4 & 7 & 7 & 5 \\
\hline 26.11 .1829 & 6,5 & 8 & 7 & & 6 & 6 & $4-5$ \\
\hline 23.01 .1838 & 7,0 & 9 & 7 & $4-5$ & 6 & 6 & $4-5$ \\
\hline 6.10 .1908 & 6,75 & 8 & 6 & 5 & 6 & 6 & 5 \\
\hline 10.11 .1940 & 7,3 & 9 & $7-8$ & 5 & 6 & 7 & 5 \\
\hline 4.03 .1977 & 7,2 & 9 & $6-7$ & 4 & $5-6$ & $5-6$ & $4-5$ \\
\hline 30.08 .1986 & 7,0 & $8-9$ & 6 & 4 & 5 & 5 & 4 \\
\hline 30.05 .1990 & 6,7 & $8-9$ & 6 & 4 & 5 & 5 & 4 \\
\hline
\end{tabular}




\section{SEISMIC HAZARD ADJUSTMENT}

The level of losses (risk) in case of a possible earthquake is the result of a combination of the structural vulnerability and seismic hazard. Currently, Ukraine is actively developing territories for the construction of not only residential buildings, but also unique, critical structures, whose destruction under seismic impacts can lead to significant economic losses and environmental disasters.

Currently, recommendations for determining the loads during seismic impacts are regulated by the requirements ${ }^{7}$. The national standard sets out the methodology for determining the class of consequences (criticality) of construction objects and regulates the selection of GSZ-2004 maps for assessing the seismic hazard of their sites. The adjustment of the seismicity of construction sites, the normative intensity of which is determined by the GSZ-2004-V and GSZ-2004-S maps, as well as of the sites located near the borders of the intensity areas, is necessarily based on special studies on seismic micro-zoning.

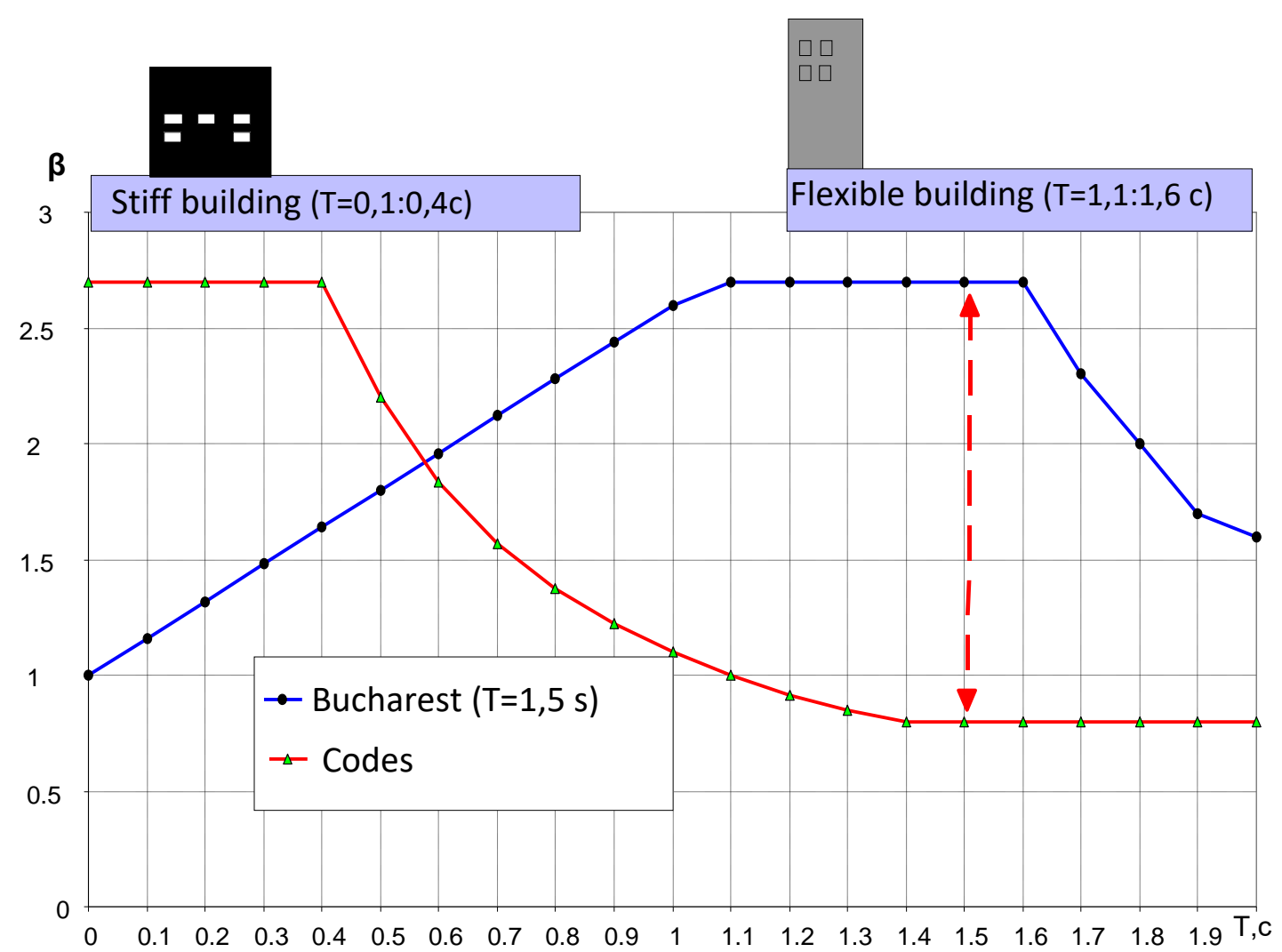

Fig. 2. Dynamic coefficient of ground movement in Bucharest (1977) during an earthquake from the Vrancea zone

7 Schnabel P.B., Lysmer J., Seed H.B. SHAKE: (1972) A Computer Program for Earthquake Response Analysis of Horizontally Layered Sites. Report № UCB. EERC-72/12. University of California, Berkeley. December (in Ukrainian). 
Ukrainian and foreign scientists performed a comparative analysis of seismic effects on the stress-strain state of critical objects ${ }^{8}$. Earthquakes in the cities of Niigata (Japan), Mexico City (Mexico), as well as the Romanian earthquake and others showed (Fig. 2), the maximum of the dynamic coefficient can shift towards low frequencies, causing resonance phenomena in the ground, increases the danger for buildings with high floors and flexible structures.

There is a need to increase the reliability of the life support systems of the country's population and reduce the risk of emergency situations during seismic events. For this, it is necessary to clarify the calculated parameters of seismic hazard taking into account the parameters of the seismic regime, regional laws of the attenuation of seismic vibrations, and the influence of local ground and morphological conditions. These reliable values are determined according to instrumental seismological observations. In order to obtain them, by joint efforts of Subbotin Institute of Geophysics of the National Academy of Sciences of Ukraine, the State Enterprise "Research Institute of Building Constructions", Odessa National Maritime University and the Ukrainian Association of Earthquake Engineering the first seismological station in Odessa was established.

A number of factors complicate the design and construction of high-rise buildings. These include: nearby seismic faults, seismic hazard, adverse geological conditions (including soils of III, IV category of seismic properties), underground workings (catacombs), landslide slopes, the presence of a high level of groundwater (flooded areas).

Soils of III and IV category in terms of seismic properties have significant nonlinear properties, which will manifest themselves in different ways, depending on the intensity and frequency composition of seismic effects. The non-linear behavior of the soil leads to a change, sometimes very significant, of the shapes and spectra of seismic waves in the soil layers. Resonant frequencies of soils turn out to be dependent on the intensity of the impact and, with sufficiently intense earthquakes, can significantly differ from the values determined by the methods of recording explosions, weak earthquakes, and short-period microseisms. Under intense seismic impacts, the geological properties of soils change; it can be associated, for example, with the movement of groundwater, the breaking of structural bonds between soil particles and other phenomena. For the amplitudefrequency characteristics of the soil environment, determined for a number of construction sites in Odessa using the Pr-shake software, ${ }^{9}$ see Fig. 3. In the calculations, the nonlinear properties of soils at the studied sites were taken into account.

${ }^{8}$ Schnabel P. B., Lysmer J., Seed H. B. SHAKE: (1972) A Computer Program for Earthquake Response Analysis of Horizontally Layered Sites. Report № UCB. EERC-72/12. University of California, Berkeley. December.

9 RBR (Republic's Building Regulations) 60-86. Inzhenernye izyskaniya dlya stroitel'stva. Seysmicheskoe mikrorayonirovanie [Engineering research for construction. Seismic microzoning]. Moskva : Gosstroy RSFSR (in Russian). 


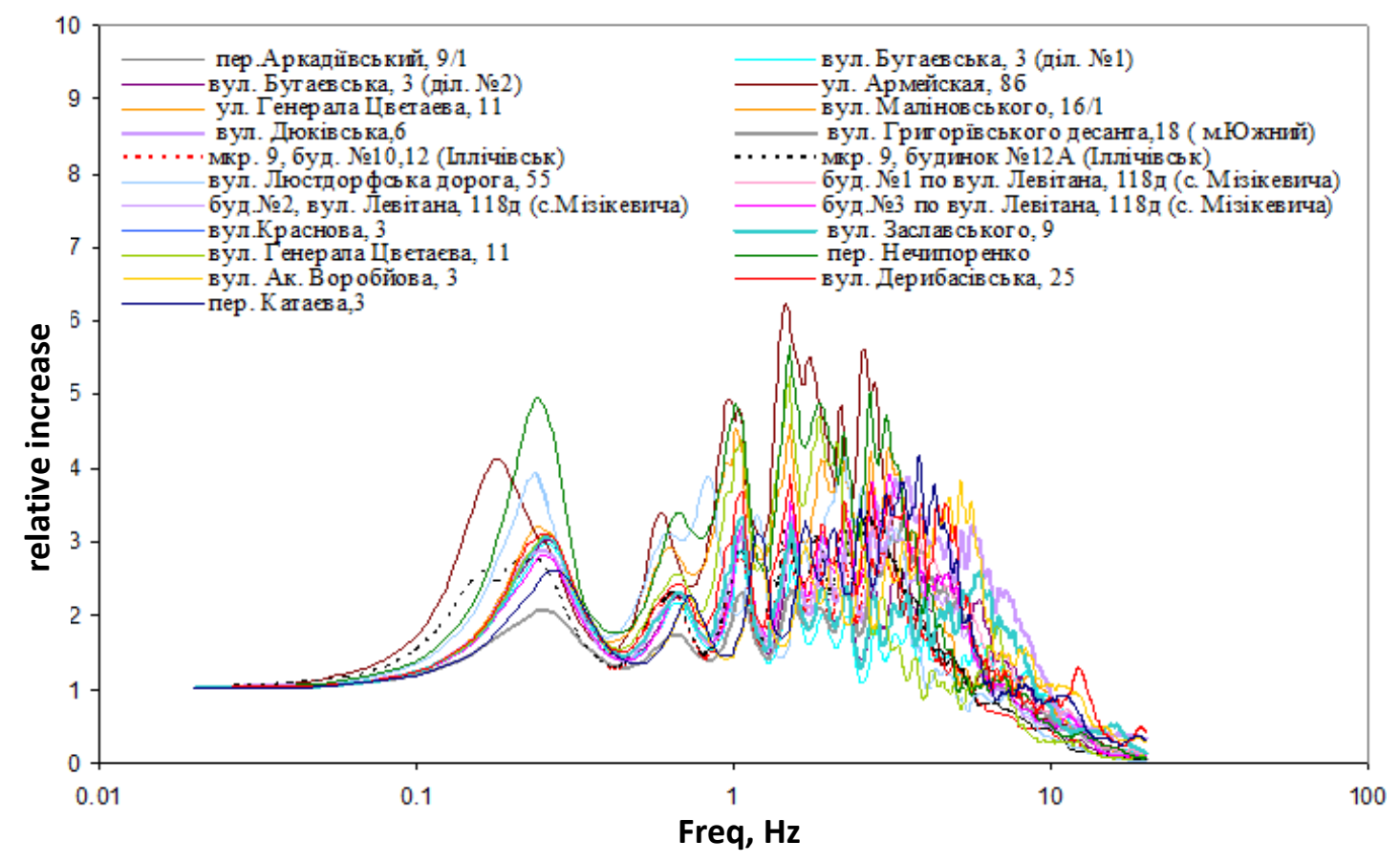

Fig. 3. Amplitude-frequency characteristics of the soils of construction sites in Odessa

Fig. 3 shows that the soil conditions of most construction sites in Odessa are characterized by a wide frequency range of possible resonant amplification. Therefore, for earthquake-resistant design of buildings and structures in Odessa, it is necessary to conduct detailed studies of the resonance properties of soils, regardless of the complexity of the design, since the natural vibration frequencies of both single-story and high-rise buildings, as a rule, lie in the frequency range in which the maxima of soil vibration amplification are observed.

With the introduction of DBN V.1.1-12: 2014, the requirements for the design and construction of high-rise buildings have changed compared to the requirements of DBN V.1.1-12: 2006:

- the requirement to take into account the first two forms of the building's own vibrations became mandatory;

- the concept of a weak earthquake (WE), a design-basis earthquake (DE), a maximum design earthquake (MDE) was introduced and the seismic loads used to design structures of various classes of consequences are delimited;

- the distinction is made between the use of general seismic zoning (GSZ) maps for buildings of various classes of consequences. The decision to select a map when designing a specific object and assigning the object to the class of consequences (criticality) is made by the general designer in accordance with DSTU (National Standards of Ukraine) - N.V.1.2-16: 2013 and is agreed with the customer. 
When designing the objects of the $\mathrm{CC} 1$ and $\mathrm{CC} 2$ consequence classes, to determine the calculated seismic intensity, it is necessary to use the GSZ-2004A map. When designing residential and public buildings with a height of more than $73.5 \mathrm{~m}$ - codes and objects classified as potentially dangerous, but not identified as an object of increased danger, it is recommended to use the GSZ2004-V card. When designing objects of the CC3 impact class, to determine the calculated seismic intensity, you need to use the GSZ-2004-S map:

- added a new calculation of structures for seismic impacts "Non-linear static calculation";

- reduced floor coefficient used in the calculation of seismic load;

- added graphs of dynamic coefficients for buildings with different values of compliance coefficients, the use of which allows reducing the magnitude of seismic load;

- for the first time, the section "Designing Building Seismic Insulation Systems" was introduced;

- the section "Slopes" containing basic requirements for the calculation of slopes was introduced for the first time.

In these standards, the following geophysical data are noted as necessary for the design of buildings and structures in seismically dangerous territories:

- information on the magnitude, duration, spectral composition and prevailing periods of soil oscillation to exclude possible resonant effects;

- the speed of the seismic wave under the site of the projected construction;

- calculated accelerograms that take into account the influence of potentially dangerous seismically active zones and soil conditions of the site of the designed construction.

To determine the quantitative characteristics of the seismic hazard of a construction site, the following work should be performed:

- seismic micro-zoning (SMR) of the site using engineering-geological analogies;

- the formation of models of the structure of the geological environment in the selected areas (taxa) according to the results of engineering-geological studies for construction ${ }^{10}$, making of a SMR map using the engineeringgeological analogies method;

- selection of a reference point in the area of the object's location, determination of geological environment parameters for it, such as the distribution of soil lithology with depth and their physical and mechanical

10 Yehupov K. V. (1991) Prichal'nye sooruzheniya estakadnogo tipa [Mooring structures of the trestle type]. Yehupov K. V., Moscow, V/O Mortekhinformreklama (in Russian). 
properties: longitudinal and shear wave velocities, density, porosity, and attenuation characteristics of seismic vibrations depending on distance;

- adjustment of the design-basis earthquake and maximum design earthquake parameters in local potentially seismically active zones and Vranchea seismically active zone at a reference point in the area of the studied site;

- seismic microregulation (SMR) of the site using seismic stiffness methods; making of the site seismic microregulation map based on the results of studying the site using geological analogies and seismic stiffness methods;

- organization and conduct of field instrumental seismological observations with the aim of recording high-frequency microseisms (earthquakes and explosions), as the most reliable basis for calculating the increase in seismic intensity, determined by the specific ground conditions of the site areas of the object, making of calculated accelerograms and reaction spectra;

- determination of seismic gain increments for each of the taxonometric units (taxa) allocated on the study site and making of the site SMR map based on the results of three methods: engineering-geological analogies, seismic stiffnesses and the method of recording earthquakes, explosions, and shortperiod microseisms;

- determination for each taxon of the distribution of soil lithology with depth and their physicomechanical properties: longitudinal and shear wave velocities, density, porosity and attenuation characteristics of seismic vibrations with distance;

- making settlement models of soil complexes for each of the selected taxa, taking into account the results of construction and installation works using seismic stiffness methods and materials of engineering and geological studies conducted in accordance with the requirements of DBN (Ukrainian national construction regulation) A.2.1-1-2014;

- calculation of the theoretical frequency characteristics of soil models for taxonometric units identified on the site according to the set of results of the three SMR methods;

- determination of the empirical frequency characteristics of soil complexes under different sections (taxa) of the study site based on the registration of earthquakes, explosions and short-period microseisms;

- construction of calculated accelerograms and reaction spectra ensemble for a design-basis earthquake and a maximum design earthquake from the Vrancea zone and local potentially seismically active zones, taking into account the empirical and theoretical frequency characteristics of soil complexes under the taxa identified on the site.

See Fig. 4 for an example of two implementations of three-component design accelerograms built for a construction site in Odessa. 


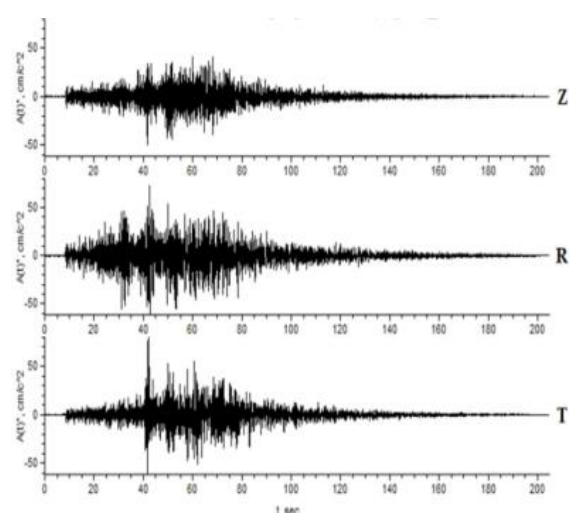

a

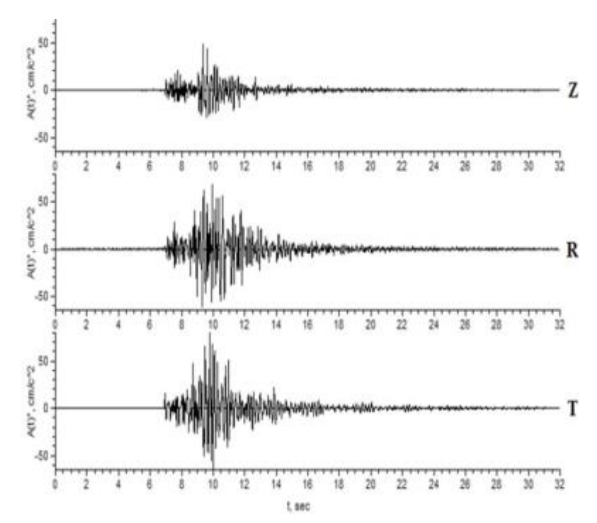

б

Fig. 4. Graphs of three-component calculated accelerograms: $a$ - from the Vrancea zone; $b$ - from the local zone

Works on seismic microzonation are intended not only to determine the value of the increment of seismic hazard (intensity) at the construction site due to the influence of its soil conditions.

The data obtained make it possible to significantly reduce the cost of earthquake-resistant construction due to the optimal choice of design solutions that avoid the coincidence of superior frequencies, correspond to peak acceleration in seismic waves, resonance frequencies of the underlying soil mass and the natural frequencies of the designed building (structure).

When generating calculated accelerograms, various combinations of theoretical bypass spectra of calculated accelerograms, normalized frequency characteristics of the medium and phase spectra obtained from different records of real subcrustal earthquakes from the Vrenchea zone and earthquakes from nearby seismically active zones, modified in view of the site conditions, are used.

\section{RECOMMENDATIONS ON THE USE OF CALCULATED ACCELEROGRAMS}

Direct dynamic calculations of buildings and structures should be performed using calculated accelerograms ai $(t)=A i$ yi $(t)$, where $i-\operatorname{sign}$ of a component of the oscillation vector; $\mathrm{Ai}$ - maximum value of the amplitude of accelerations; $y(t)$ - unit-normalized function that describes the time variation of the soil.

When designing particularly important objects in direct dynamic calculations, one should use calculated accelerograms constructed for a given probability of not exceeding the maximum seismic influences, which corresponds to the GSZ maps. The calculated accelerograms are based on instrumental records of strong and intermediate magnitude earthquakes recorded directly at the construction site, or in conditions close to the site conditions. The values of $\mathrm{Ai}$ in this case are determined using work to clarify the seismic hazard of the site. 
When designing atypical and critical buildings and structures in direct dynamic calculations, the use of synthesized calculated accelerograms based upon the conditions of the site is allowed.

In the absence of instrumental records for the generation of calculated accelerograms, calculation methods and data on the increment of seismic scores due to the influence of local soil conditions of the site obtained during its seismic microzoning can be used.

When designing buildings and structures not for a particular site, in direct dynamic calculations it is recommended to use a package of three-component synthesized accelerograms, which were built on the basis of soil vibration records recorded in different regions of Ukraine using digital seismic stations.

When performing direct dynamic calculations of buildings and structures, the amplitudes of the synthesized accelerograms must be multiplied by a scale factor K, the value of which depends on the seismicity of the site.

The maximum values of the accelerations refer to the horizontal components of the oscillations. In the absence of instrumental records, the values of the vertical accelerations of the base can be taken equal to 0.7 of the values of horizontal accelerations.

When conducting direct dynamic calculations using a set of synthesized accelerograms, it is necessary to take those in which the periods with oscillations superior in amplitude are close to the periods of natural oscillations of the building in the first form.

Recommendations for the selection of design accelerograms should take into account their compliance for a particular site in terms of the main seismological parameters:

- magnitude;

- epicentral distance;

- depth and mechanism of the focus;

- the ground conditions of the site, etc.

The values of seismic loads, displacements and deformations of structures should be determined taking into account the features of nonlinear deformation of structures.

In the case of separate use in the calculations of buildings and structures on the seismic effects of horizontal and vertical components of accelerograms, the most dangerous directions of seismic effects should be used.

Direct dynamic calculations of buildings with seismic isolation systems, with adaptive seismic protection systems (included and excluded), dynamic vibration dampers, damping devices and other seismic protection elements should be carried out with scientific support and with the participation of organizations licensed to perform this type of work ${ }^{11}$.

${ }^{11}$ Dorofeev V., Yehupov K. Y., Murashko A., Adamov O. (2014) "A new approach to buildings seismic resistance assessment in Ukraine", Proceedings of the 2-nd European Conference on Earthquake Engineering and Seismology. Istambul, Turkey, pp. 138-143, 2014. 


\section{FIELD RESEARCH EQUIPMENT AND TECHNIQUES}

Microseismic recording was performed by two Das-05 three-channel digital seismic stations, the last of the lineup of automatic seismic stations manufactured at Institute of Geophysics of NAS of Ukraine. CM-3KB were used as seismic receivers (see. Fig. 5).

The DAS-05 seismic station provides:

- registration of the full vector of seismic vibrations in the dynamic range of at least $140 \mathrm{~dB}$;

- measured information registration frequency in the range of $0.012-100 \mathrm{~Hz}$;

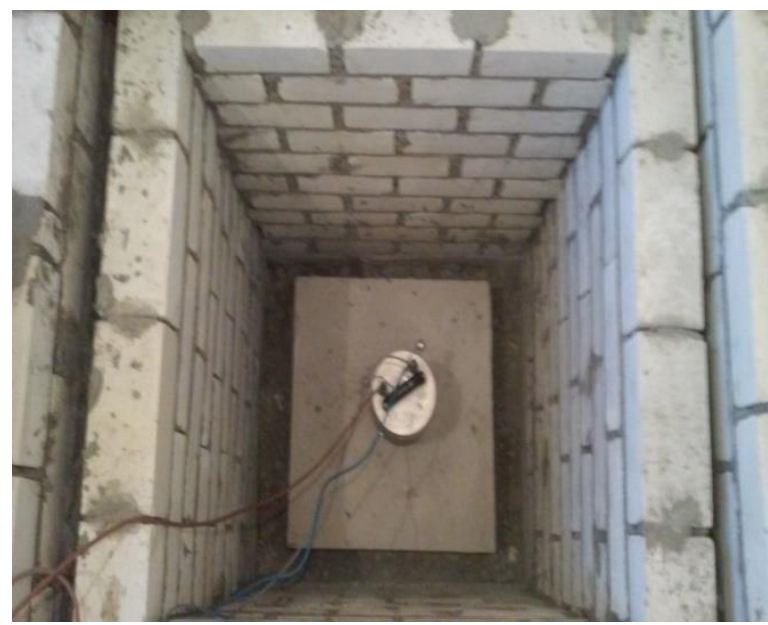

Fig. 5. General view of the "Odessa-misto" seismic station at Odessa National Maritime University

Acceleration, velocity and displacement time-histories: 20180425,720 n.gcf

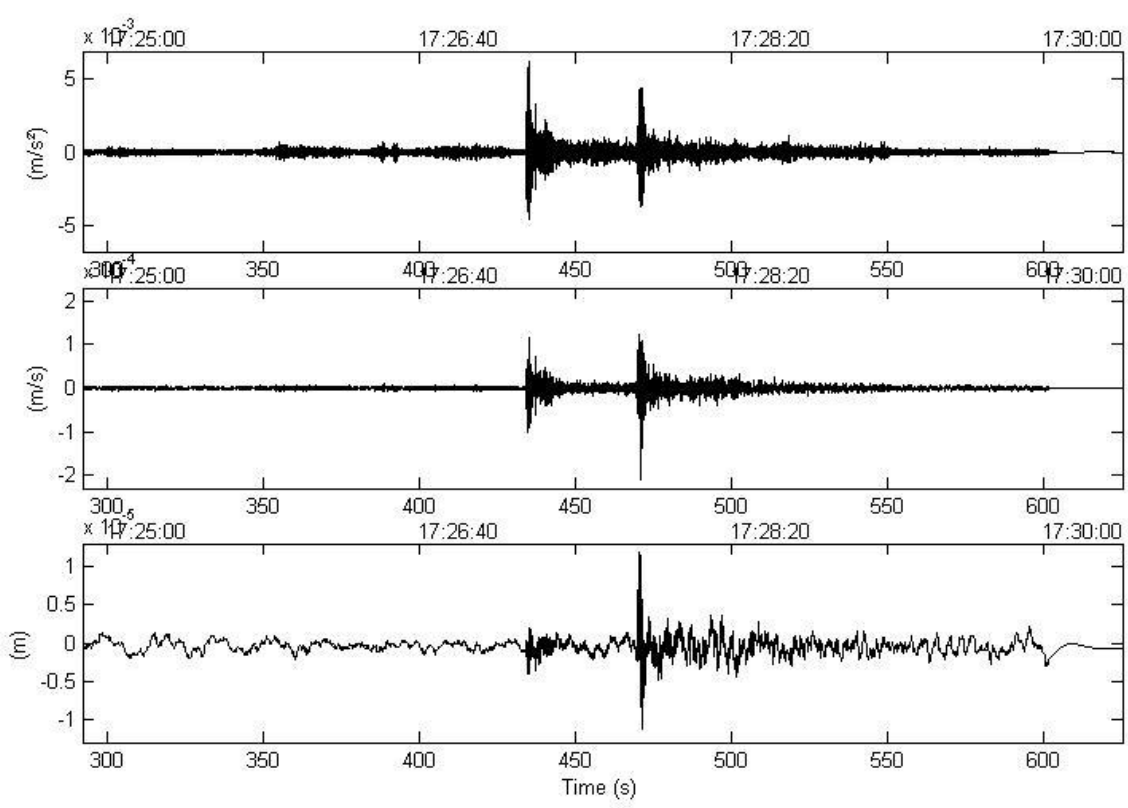

Fig. 6. Record of an earthquake from the Vrancea zone by "Odessa-misto" station 

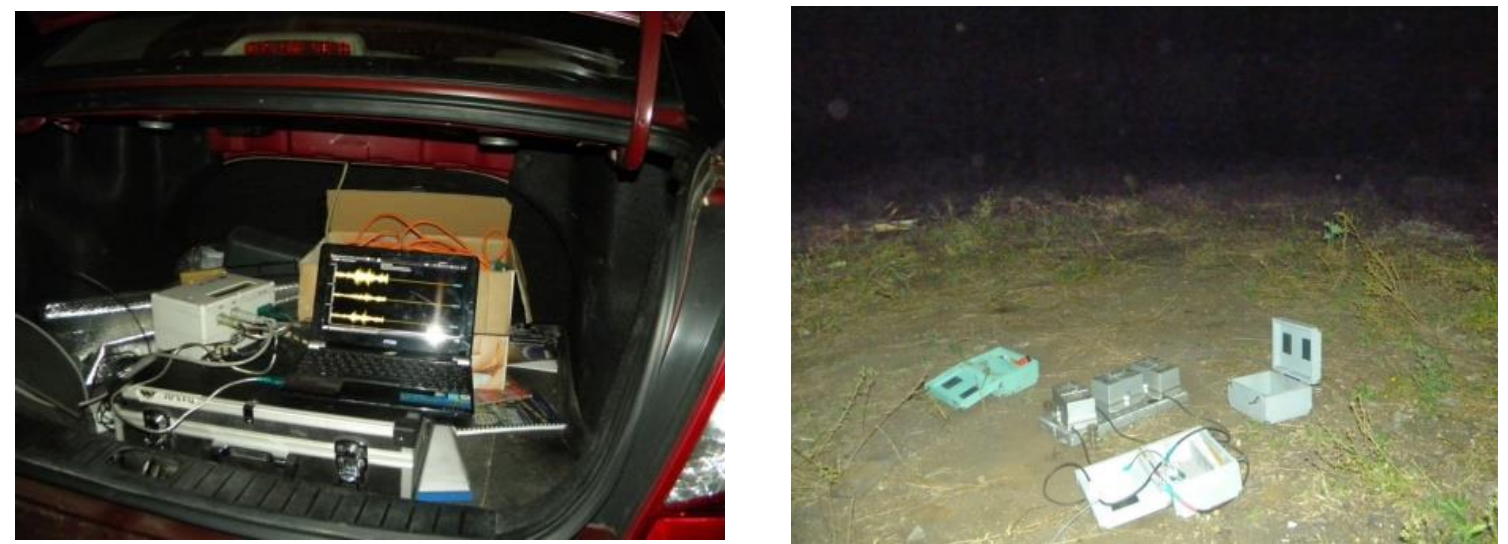

Fig. 7. Seismic station "DAS-05"

- synchronization of recorded signals with a standard time in GMT with an accuracy of at least $0.1 \mathrm{~ms}$;

- the relative error of the integrated clock not higher than 10-7 s;

- regular correction of the built-in clock of the radio signal of the exact time received from the satellite gps receiver;

- the ability to work with automatic switching both from a $220 \mathrm{~V}$ power supply network and from a rechargeable battery (12-24 V);

- energy intensity control and automatic charging of the rechargeable battery in the mode of operation from the network;

- standby power consumption of not more than 10 watts;

- at least 24 hours battery life of the equipment using rechargeable batteries;

- calibration of seismic channels (it is possible to determine the amplitude and phase frequency characteristics of seismic channels with an accuracy of $5 \%$ in the frequency range of 0.01 to $50 \mathrm{~Hz}$ ) allows you to obtain the information necessary to determine the actual values of acceleration, velocity or displacement in the recorded oscillations.

The frequency response of the digital seismic station is calculated by the generator method with the help of a special program. The registered seismic signals have a unit dimension of an analog-to-digital converter (ADC). The digital form of recording allows using the methods of regularized numerical solution of the inverse seismometry problem to switch to the "real" mode of vibrations. To do this, use the frequency characteristics (FC) of the recording channels. For the amplitude-frequency and phase-frequency characteristics of the measuring channels see Fig. 8. 


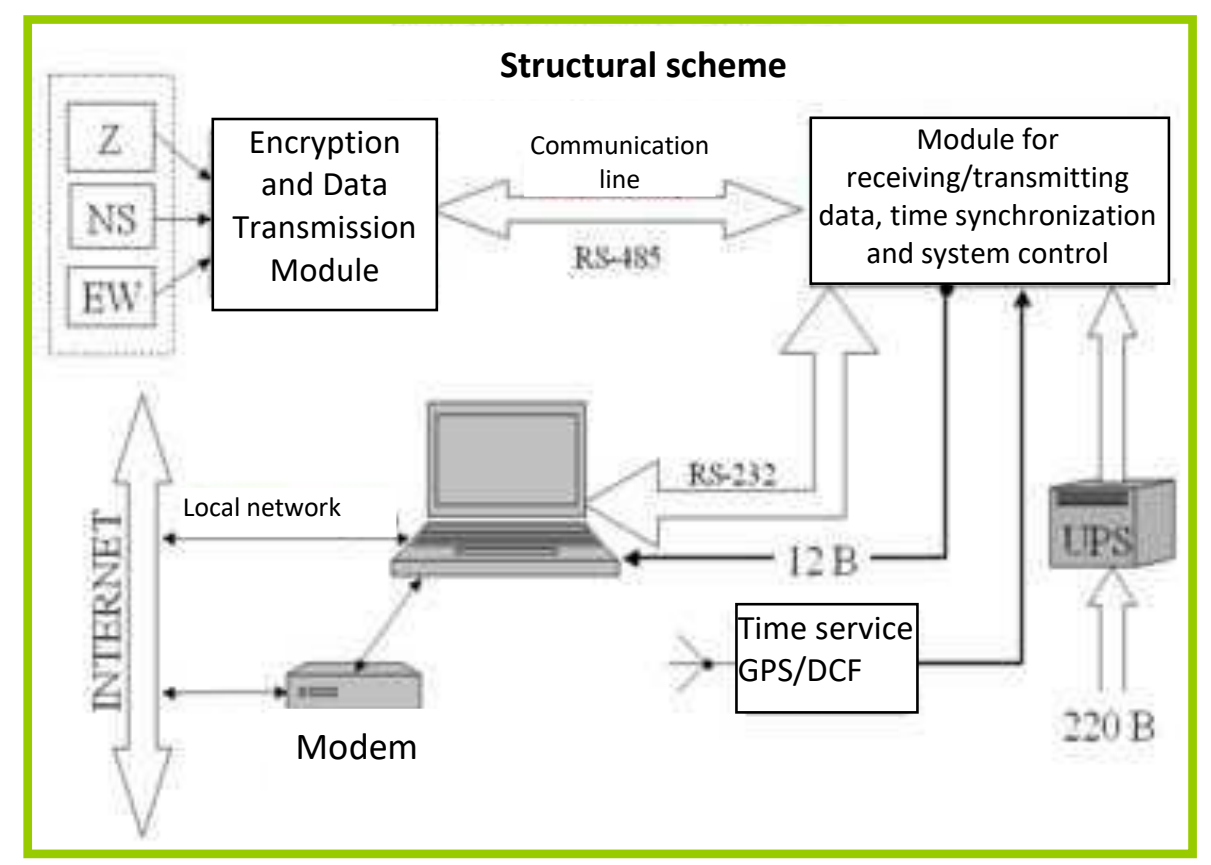

Fig. 8. The structural diagram of the "DAS-05" seismic station

\section{CLARIFICATION OF SEISMIC VULNERABILITY}

In addition to seismic hazard, the second component of seismic risk is seismic vulnerability. A lot of research in this field has been carried out by our group, on the basis of which two dissertations were prepared for defense (for a doctor's degree by A. Murashko, and Ph.D by I. Benradi). The methodological base for assessing the seismic resistance of buildings and structures, developed in the form of a three-level system for assessing the actual seismic resistance (hereinafter - SAASR) and is based on various approaches to determining seismic vulnerability ${ }^{12}$.

In that regard, laboratory full-scale and numerous studies were performed. Fig. 9-11

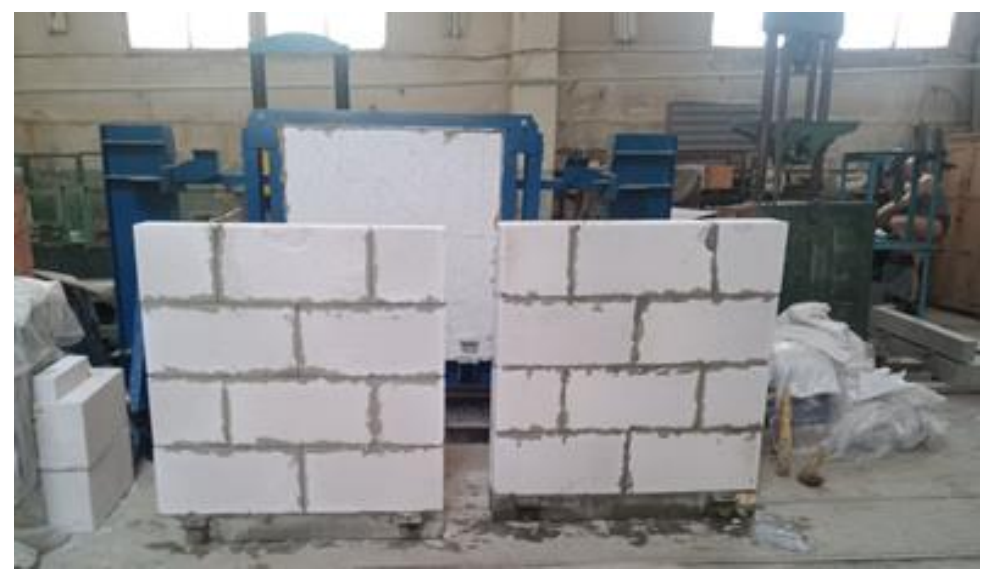

Fig. 9. Test bench for wall panels and panel samples

12 FEMA 154. (2015) Rapid Visual Screening of Buildings for Potential Seismic Hazards. A Handbook Edition 3, FEMA. 
As a result of the studies, the test procedure for the second and third levels of SAASR and numerous simulations was determined, the need to take into account the non-load bearing wall filling was revealed.

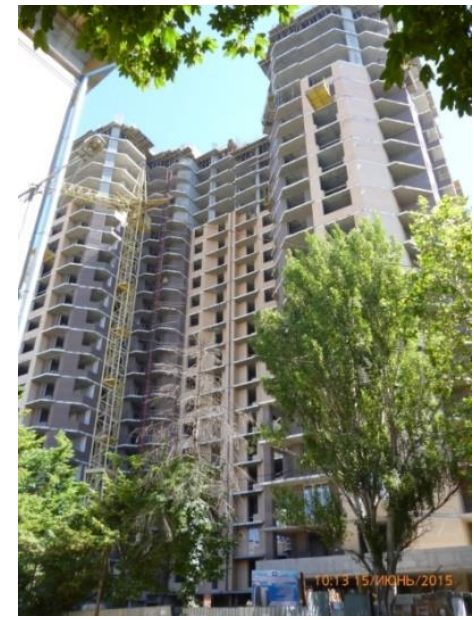

a)

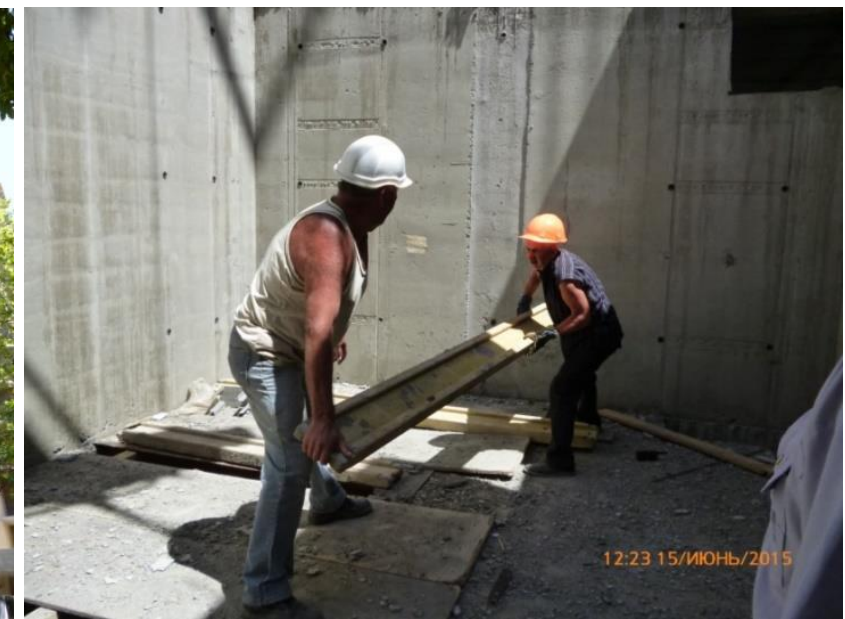

b)

Figure 10. Object of field studies, a) - Photo fixation of facility

b) - Tamper strikes in the elevator section
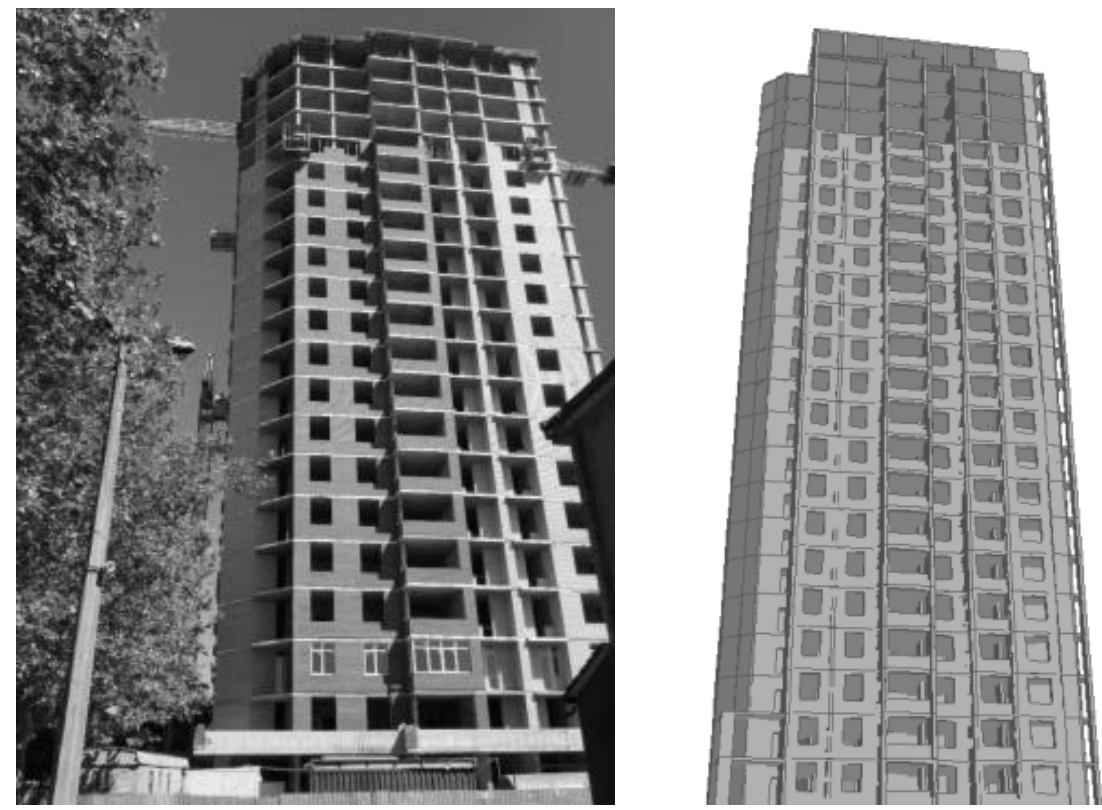

Fig. 11. General view of the tested building and design scheme with regard to the wall fencing

Assessment of actual seismic resistance of the 1st level (AASR-1). To assess the seismic risk of territories and develop planned measures to increase seismic resistance to ensure the necessary level of reliability, as well as develop a set of measures to eliminate the effects of earthquakes in world experience, a form based on the results of a visual survey, is used. 
Such a system will be partially similar to the American FEMA 154 Rapid Visual Screening of Buildings for Potential Seismic Hazards system ${ }^{13}$ and many others developed on its basis and adapted to the characteristic conditions of various states (India, Turkey, etc.). For this type of assessment, it is necessary to develop our own methodology for operational assessment, in view of the Ukrainian specifics of construction. For a sample of this form used in assessing the earthquake resistance of an existing building ${ }^{14}$, see Table 3 .

Assessment of actual seismic resistance of the 2nd level (AASR-2). A formalized approach to the assessment of seismic resistance in the form of certification for mass construction projects, which should be implemented in accordance with the requirements of DBN (Ukrainian national construction regulation) V. 1.1-12:2006, and later DBN (Ukrainian national construction regulation) V. 1.1-12:2014. At this level, a combination of numerical and field studies will make it possible to assess the earthquake resistance of an object based on a larger amount of information compared to AASR-1, and as a result, the reliability of this estimate will be greater.

Assessment of actual seismic resistance of the 3rd level (AASR-3). For experimental construction objects, high critical and unique objects, it is necessary not only to carry out engineering-seismometric tests, but also to calculate the work of building structures using numerical modeling of the nonlinear work of building structures under seismic effects, which describes it using accelerograms recorded at the construction site. Based on the described combination of experimental and computational operations, we can conclude what is the actual seismic resistance of a particular object, taking into account

${ }^{13}$ Murashko O.V., Ilham B., Abdelhadi M (2020) Approval of the developed visual assessment of seismic resistance, taking into account the irregular wall infill bulletin of Odessa state academy of civil engineering and architecture collection of scientific works. Odessa : OSACEA, 2020. March. № 78. p. 34-40 ISSN 2415-377X, DOI: 10.31650/2415-377X-202078-34-40

14 Lapkina I. A., Boldireva T. V. (2009) Pamyati osnovateley nauchnoy shkoly optimalnogo upravlenia na morskom transporte [To the memory of founders of scientific school of optimal management on marine transport] Development of Management and Entrepreneurship Methods on Transport. issue 15, pp. 5-16. [in Russian].

${ }^{2}$ Morozova I. V., Lapkina I. A., Boldireva T. V. (2010) Nauchnaya shkola optimalnogo upravlenia na morskom transporte; sinergetika znaniy pokoleniy [Scientific school of optimal management on marine transport:synergetic of generations knowledge] Herald of the Odessa National Maritime university: Collection of Scientific Papers. issue 31, pp. 134-141. [in Russian].

3 (2019) Proektniy ta logistychniy menedzhment: novi znannya na bazi dvokh metodologiy.[Project and Logistics Management: new knowledge on the base of two methodologies. Part 1.1. "Foundation and development in ONMU economic-mathematical direction in economic science and management at marine transport"]: Monograph, vol. 2 [I. O. Lapkina, V. O. Andryyevs'ka, V. Yu. Smrkovs'ka ta in.], Odesa, pp. 7-31. DOI: 10.21893/2616-8936.2019-02 [in Ukrainian]. 
the real characteristics of the structures and the impact that was recorded at the site where the object is located.

\section{Form of seismic assessment of the object}

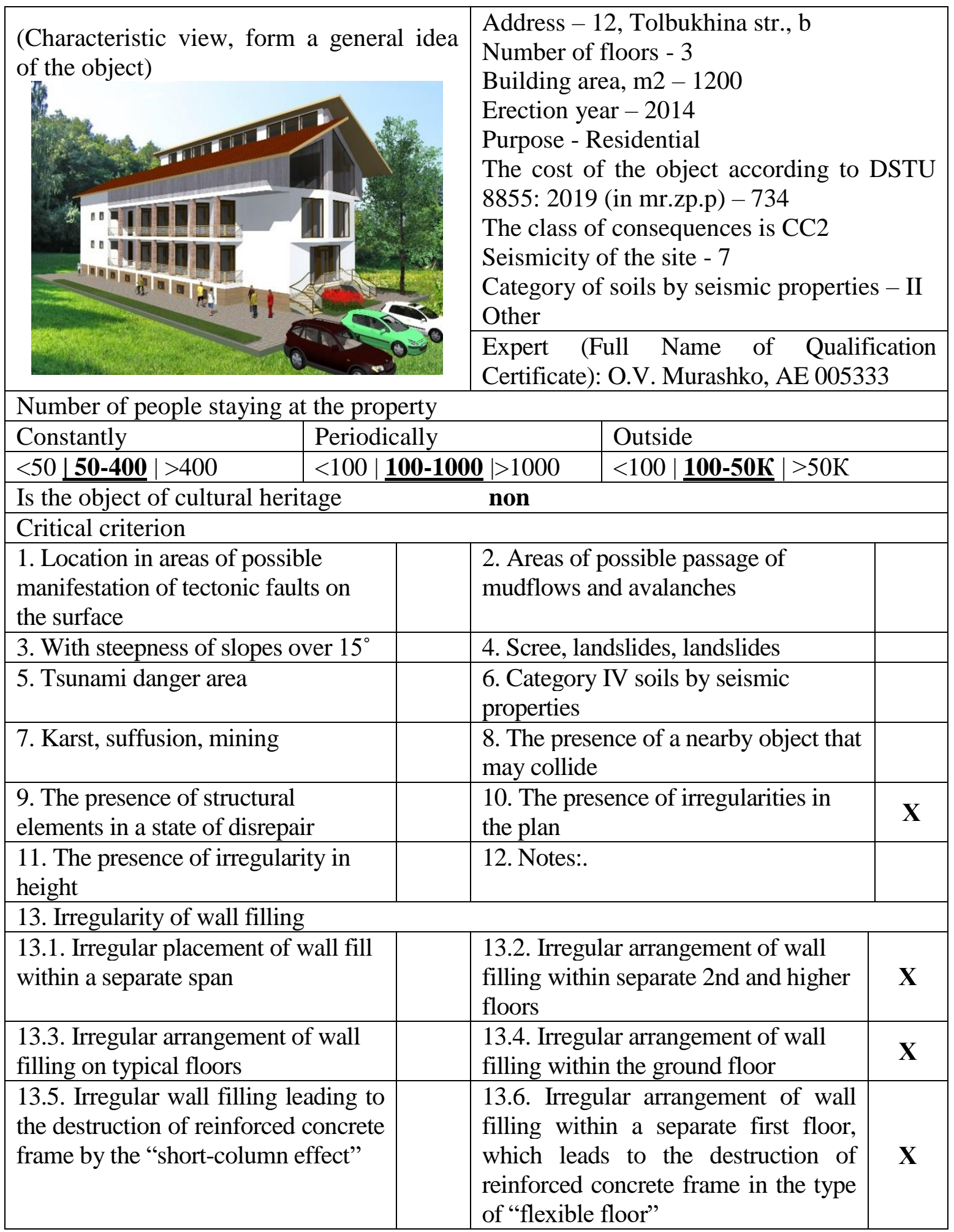


Table 3 (continuance)

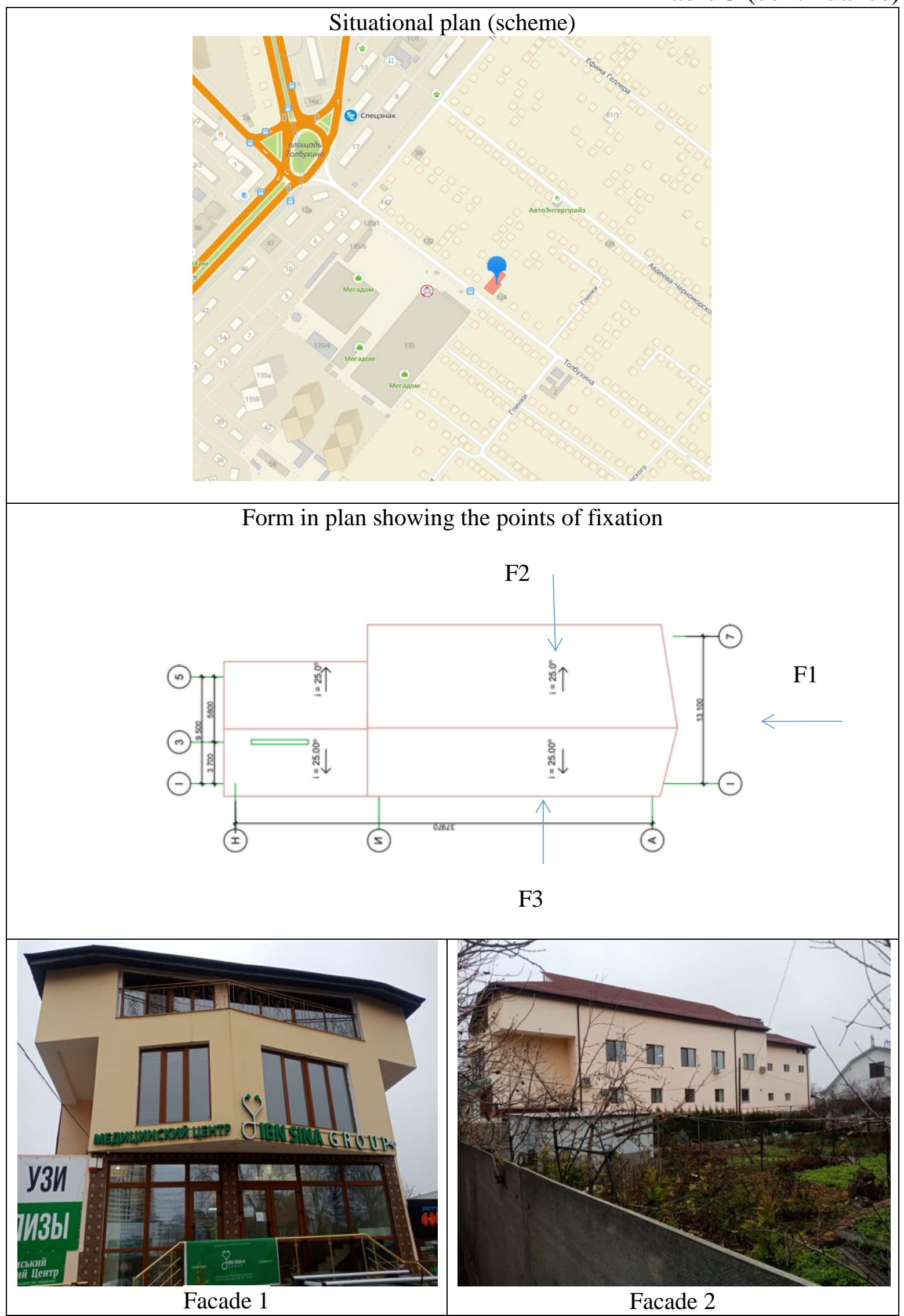


Table 3 (ending)

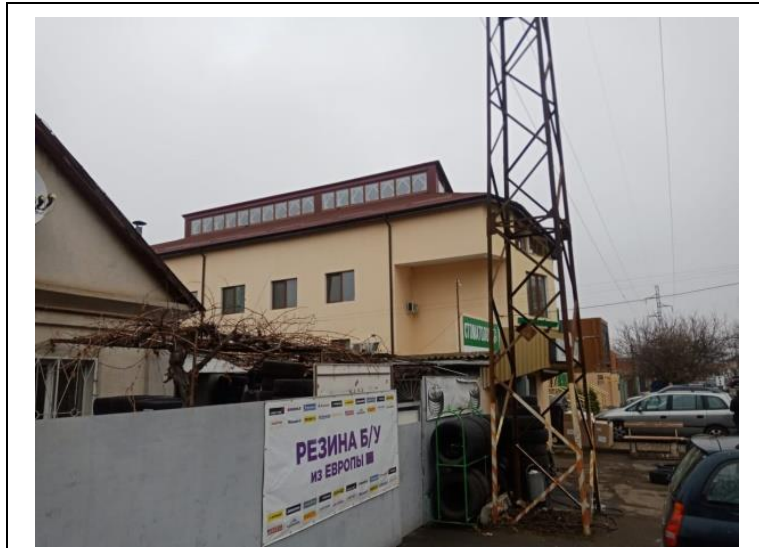

Facade 4

access to the rear facade

was not provided

Facade 3

\section{Photo fixation of detected critical criteria of the object (if detected)}

Critical criteria \# 10, 11, 13.2, 13.4, 13.6 are visible on facades \# 1 and \# 2

\section{Expert opinion}

The facility is potentially non-seismic and requires certification (Level 2 SOFs)

\section{CONCLUSIONS}

Odessa School of Earthquake Engineering, established in 1958, has created an extensive research platform, which allows to significantly improve the definition of seismic risk.

1. The first main task is the determination of seismic hazard, for which the following was performed:

1.1. The equipment and methods of field research have been developed, which allows you to get real data on soil vibrations at construction sites.

1.2. A semi-empirical method for constructing calculated accelerograms has been developed, which is based on the maximum use of the information contained in the accelerogram of earthquakes from local focal zones and earthquakes of the Vrancea zone recorded in the city of Odessa.

1.3. The seismic effect of local engineering and geological conditions at construction sites was analyzed. Using theoretical modeling of seismic effects and numerous experiments, it was found that filtering seismic waves by the geological environment and the occurrence of resonant vibrations in structures during strong subcrustal earthquakes in the Vrancea zone can lead to several times increase in seismic loads.

1.4. It was proved that the calculated accelerograms and reaction spectra constructed based upon the results of seismic micro-zoning open up the possibility of cheapening seismic-resistant construction due to the optimal choice of design solutions that avoid the coincidence of superior frequencies corresponding to peak acceleration in seismic waves, resonant frequencies of 
the underlying soil stratum and natural frequencies of the designed buildings and structures while maintaining the necessary reliability.

1.5. A three-level system for assessing the actual seismic resistance has been developed, which allows for the phased determination of the seismic vulnerability of buildings in seismic areas.

2. The second main task is the determination of seismic abrasiveness, for which the following was performed:

2.1. A series of full-scale, laboratory and numerous studies were conducted to determine the actual seismic resistance of buildings.

2.2. The approach to the numerical modeling of buildings under seismic effects was developed, taking into account the real behavior of load-bearing and non-load-bearing elements.

2.3. A three-level system for assessing the actual seismic resistance has been created, which includes a visual assessment, certification and detailed studies carried out according to an individual program.

3. The obtained research results were used in the scientific and technical support of the design, reconstruction and erection of real buildings and structures, and the proposed approaches, models and applied techniques were tested in assessing the bearing capacity and deformability of buildings and structures.

\section{SUMMARY}

The article is devoted to description of main direction of Odessa school of earthquake-resistant construction that was created by professor V.K. Iegupov to the reduction of seismic risk, which is connected with a combination of the structural vulnerability and seismic hazard. So the two main problems raised in the article are the assessment of structural vulnerability and seismic hazard

Seismic regions with an estimated earthquake intensity of 7,8 and 9 points occupy up to $20 \%$ of the territory of Ukraine. They have many industrial and cultural centers with large volumes of construction. The rational design of earthquake-resistant structures, increasing their reliability is of great economic importance.

The basic approaches to the conduct of seismic microzoning are analyzed; A practical approach to specifying the predicted seismic intensity of the building sites is proposed, taking into account the results of detailed seismic zoning (DSR) and seismic microzoning; developed equipment and methods of field research; semiempirical method of constructing calculated accelerograms was developed; It has been established that irregularities of the field of oscillations of the soil, seismic wave filtration into the geological environment and the occurrence of resonant oscillations in buildings under strong suburban earthquakes in the Vranch zone can lead to an increase in seismic loads several times. A recommendation is proposed that the seismicity of the construction sites should be performed on the basis of seismic microzoning. 
In the direction of the assessment of structural vulnerability series of fullscale, laboratory and numerical studies were conducted to determine the actual seismic resistance of buildings.

Also the approach to the numerical modeling of buildings under seismic effects was developed, taking into account the real behavior of load-bearing and non-load-bearing elements.

A three-level system for assessing the actual seismic resistance has been created, which includes a visual assessment, certification and detailed studies carried out according to an individual program.

\section{REFERENCES}

1. Iegupov V. K. (1965) Raschet zdaniy na prochnost', ustoychivost' i kolebaniya [Calculation of buildings for strength, stability and fluctuations]. "Budivelnik", Kyiv (in Russian).

2. Iegupov V. K., Komandrina T. A. (1969) [Calculation of buildings for seismic impacts] "Budivelnik", Kyiv (in Russian).

3. Iegupov V. K., Komandrina T. A., Goloborodko V. N. (1976) Prostranstvennye raschety zdaniy (posobie po proektirovaniyu) [Spatial calculations of buildings (design manual)], "Budivelnik", Kyiv (in Russian).

4. Iegupov V. K., Iegupov K.V., Lukash E. P. (1982) Prakticheskie metody rascheta zdaniy na seysmostoykost' [Practical methods of calculating buildings for earthquake resistance]. "Budivelnik", Kyiv (in Russian).

5. DBN 1.1-12: 2014. (2014) Stroitel'stvo v seysmicheskikh rayonakh Ukrainy [Ukrainian national construction regulation. Construction in seismic areas of Ukraine]. Kyiv: Ministry of Regional Development of Ukraine, Ukrarkhbudinform (in Ukrainian).

6. Nemchinov Yu. I. (2008) Seysmostoykost' zdaniy i sooruzheniy [Seismic resistance of buildings and structures]. In 2 parts (in Russian).

7. Schnabel P. B., Lysmer J., Seed H. B. SHAKE: (1972) A Computer Program for Earthquake Response Analysis of Horizontally Layered Sites. Report № UCB. EERC-72/12. University of California, Berkeley. December.

8. DBN V.1.1-12: 2006. (2006) Stroitel'stvo v seysmicheskikh rayonakh Ukrainy [Ukrainian national construction regulation. Construction in seismic areas of Ukraine]. Kyiv: Ministry of Construction, Architecture and Housing and Communal Services of Ukraine, Ukrarchbudinform. (in Ukrainian).

9. RBR (Republic's Building Regulations) 60-86. Inzhenernye izyskaniya dlya stroitel'stva. Seysmicheskoe mikrorayonirovanie [Engineering research for construction. Seismic microzoning]. M.: Gosstroy RSFSR (in Russian).

10. BCaR II-7-81*. (1985) Stroitel'nye normy i pravila. Stroitel'stvo v seysmicheskikh rayonakh [Building Codes and Regulations. Construction in seismic areas]. Moscow (in Russian). 
11. Iegupov K. V. (1991) Prichal'nye sooruzheniya estakadnogo tipa [Mooring structures of the trestle type] Iegupov K. V., Moscow, V/O Mortekhinformreklama (in Russian).

12. V. Dorofeev, K. YIegupov, A. Murashko, O. Adamov (2014) "A new approach to buildings seismic resistance assessment in Ukraine", Proceedings of the 2-nd European Conference on Earthquake Engineering and Seismology. Istambul, Turkey, pp. 138-143, 2014.

13. FEMA 154. (2015) Rapid Visual Screening of Buildings for Potential Seismic Hazards. A Handbook Edition 3, FEMA.

14. Murashko O. V., Ilham B., Abdelhadi M (2020) Approval of the developed visual assessment of seismic resistance, taking into account the irregular wall infill bulletin of Odessa state academy of civil engineering and architecturecollection of scientific works. Odessa: OSACEA, 2020. March № 78. P. 34-40. ISSN 2415-377X, DOI: $10.31650 / 2415-377 X-2020-78-34-40$.

Information about the authors: Iegupov K. V., Doctor of Technical Sciences, Professor,

Director of the Research Institute of Fundamental and Applied Research,

Odessa National Maritime University 34, Mechnikov str., Odessa, 65029, Ukraine ORCID ID: orcid.org/0000-0002-8342-820X

Iegupov V. K., Ph.D., Leading Engineer, Subotin Institute of Geophysics, National Academy of Sciences of Ukraine 32, Academician Palladin str., Kyiv, Ukraine ORCID ID: orcid.org/0000-0001-5093-6948

Murashko O. V., Ph.D., Associate Professor, Odessa State Academy of Civil Engineering and Architecture 4, Didrihsona str., Odessa, 65029, Ukraine ORCID ID: orcid.org/0000-0002-2812-5951 